Purdue University

Purdue e-Pubs

Purdue CIBER Working Papers

Krannert Graduate School of Management

$1-1-1994$

\title{
Beyond the Lecture: Case Teaching and the Learning of Economic Theory
}

John A. Carlson

Purdue University

David W. Schodt

St. Olaf College

Follow this and additional works at: http:// docs.lib.purdue.edu/ciberwp

Carlson, John A. and Schodt, David W., "Beyond the Lecture: Case Teaching and the Learning of Economic Theory" (1994). Purdue CIBER Working Papers. Paper 87.

http://docs.lib.purdue.edu/ciberwp/87

This document has been made available through Purdue e-Pubs, a service of the Purdue University Libraries. Please contact epubs@purdue.edu for additional information. 
THE MEDIATING EFFECTS OF ORGANIZATION COMMITMENT AND JOB INVOLVEMENT ON THE RELATIONSHIP BETWEEN QUALITY OF WORK LIFE AND CUSTOMER SERVICE ATTITUDES

\author{
John Hannon \\ Purdue University \\ Ing-Chung Huang \\ National Sun Yat-sen University - Taiwan \\ Cheng-Chen Lin \\ National Sun Yat-sen University - Taiwan \\ Visiting Scholar - Purdue University
}

94-019
Center for International Business Education and Research Purdue University
Krannert Graduate School of Management 1310 Krannert Building
West Lafayette, IN 47907-1310
Phone: (317) 494-4463
FAX: (317) 494-9658


The Mediating Effects of Organization Commitment and Job Involvement on the Relationship Between Quality of Work Life and Customer Service Attitudes

John Hannon

Assistant Professor of Human Resource Management

Krannert Graduate School of Management

Purdue University

West Lafayette, IN 47907 USA

HANNON@mgmt.purdue.edu

(317) 494-5871 voice

(317) 494-9658 fax

Ing-Chung Huang

Professor of Human Resource Management

National Sun Yat-sen University

Kaohsiung, TAIWAN

Cheng-Chen Lin

Ph.D. Candidate

National Sun Yat-sen University

and

Visiting Scholar

Purdue University 


\title{
The Mediating Effects of Organization Commitment and Job Involvement on the Relationship Between Quality of Work Life and Customer Service Attitudes
}

\begin{abstract}
In the last two decades, organizations have recognized, indeed fixated upon, the importance of quality and quality management. One manifestation of this is the emergence of the total quality management (TQM) movement, which has been proclaimed as the latest and optimal way of managing organizations. Likewise, in the domain of human resource management, the concept of quality of work life (QWL) has also received much attention of late from theoreticians, researchers, and practitioners. However, little has been done to build a bridge between these two increasingly important concepts, QWL and TQM. The purpose of this research is to empirically examine the relationship between quality of work life (the internalized attitudes employees' have about their jobs) and an indicator of TQM, customer service attitudes, CSA (the externalized signals employees' send to customers about their jobs). In addition, this study examines how job involvement and organizational commitment mediate the relationship between QWL and CSA.
\end{abstract}




\section{INTRODUCTION}

Quality and quality management have become increasingly important topics for both practitioners and researchers (Anderson, Rungtusanatham, \& Schroeder, 1994). Among the many quality related activities that have arisen, the principle of total quality management (TQM) has been advanced as the optimal approach for managing people and processes. Indeed, it is considered by some to be the key to ensuring the long-term viability of organizations (Feigenbaum, 1982). Of course, many companies have invested heavily in total quality efforts in the form of capital expenditures on plant and equipment, and through various human resource management programs designed to spread the quality gospel.

However, many still argue that there is insufficient theoretical development and empirical evidence for the determinants and consequences of quality management initiatives (Dean \& Bowen, 1994). After reviewing the relevant research literatures, we find that three problems persist in the research on TQM. First, a definition of quality has not been agreed upon. Even more problematic is the fact that many of the definitions that do exist are continuously evolving. Not surprisingly, these variable definitions often lead to inconsistent and even conflicting conclusions, Second, very few studies have systematically examined these factors that influence: the quality of goods and services, the implementation of quality activities, or the performance of organizations subsequent to undertaking quality initiatives (Spencer, 1994). Certainly this has been true for quality-related human resource management interventions. Last, TQM has suffered from an "implementation problem" (Reger, Gustafson, Demarie, \& Mullane, 1994, p. 565) which has prevented it from transitioning from the theoretical to the applied.

In the domain of human resource management, quality of working life (QWL) has also received a fair amount of attention of late from theorists, researchers, and practitioners. The underlying, and most important, principles of QWL capture an employee's satisfaction with and feelings about their: work, work environment, and organization.

Most who study QWL, and TQM for that matter, tend to focus on the importance of employee systems and organizational performance, whereas researchers in the field of HRM 
usually emphasize individual attitudes and individual performance (Walden, 1994). Furthermore, as Walden (1994) alludes to, there are significantly different managerial prescriptions and applied levels for routine human resource management processes, such as selection, performance appraisal, and compensation, than there are for TQM-driven processes, like teamwork, participative management, and shared decision-making (Deming, 1986, 1993; Juran, 1989; M. Walton, 1986; Dean \& Bowen, 1994). To reiterate, these variations are attributable to the difference between a mico focus on employees as opposed to a more macro focus on employee systems. These specific differences are but a few of the instances where the views of TQM and the views of traditional HRM are not aligned (Cardy \& Dobbins, 1993).

In summary, although TQM is a ubiquitous organizational phenomenon; it has been given little research attention, especially in the form of empirical studies. Therefore, the goal of this study is to provide an empirical assessment of how one, internalized, indicator of HRM effectiveness, QWL, is associated with one, externalized, indicator of TQM, customer service attitudes, CSA. In doing so, it bridges the gap between "employee-focused" HRM outcomes and "customer-focused" TQM consequences. In addition, it examines the mediating effects of organizational commitment and job involvement on this relationship.

\section{QUALITY OF WORK LIFE AND CUSTOMER SERVICE ATTITUDES}

In this section, we introduce and review the main principles of customer service attitudes, CSA, and discuss its measurement. Thereafter, our extended conceptualization and measurement of QWL will be presented. Finally, two variables hypothesized to function as mediators of the relationship between CSA and QWL, organization commitment and job involvement, will be explored.

\section{Customer Service Attitudes (CSA)}

Despite all the ruminations about it in the business and trade press, TQM still remains an ambiguous notion, one that often gives rise to as many different definitions as there are observers. Some focus on the presence of organizational systems. Others, the importance of leadership. Many stress the need to reduce variation in organizational processes (Deming, 1986). A number 
emphasize reducing costs through quality improvement (P.B. Crosby, 1979). Still others focus on quality planing, control, and improvement (Juran, 1989). Regardless of these differences, however, the most important, generally agreed upon principle is to be "customer focused" (Feigenbaum, 1982). The cornerstone for this principle is the belief that customer satisfaction and customer judgments about the organization and its products are the most important determinants of long-term organizational viability (Oliva, Oliver \& MacMillan, 1992). Not surprisingly, this belief is a prominent tenet in both the manufacturing and service sectors alike.

Conventional wisdom holds that quality can best be evaluated from the customers' perspective. Certainly, customers can easily articulate how well a product or service meets their expectations. Therefore, managers and researchers must take into account subjective and cognitive factors that influence customers' judgments when trying to identify influential customer cues, rather than just relying on organizational presumptions. Recently, for example, Hannon \& Sano (1994) described how customer-driven HR strategies and practices are pervasive in Japan. An example they cited was the practice of making the top graduates from the best schools work in low level, customer service jobs for their first 1-2 years so that they might better understand customers and their needs.

To be sure, defining quality in terms of whether a product or service meets the expectations of customers is all-encompassing. As a result of the breadth of this issue, and the limited research on this topic, many important questions about the service relationship, particularly those pertaining to exchanges between employees and customers, linger. Some include, "What are the key dimensions of service quality?" and "What are the actions service employees might direct their efforts to in order to foster good relationships with customers?"

Arguably, the most readily obvious manifestations of quality for any customer are the service attitudes of employees. In fact, during the employee-customer interaction, conventional wisdom holds that employees' customer service attitudes influence customer satisfaction, customer evaluations, and decisions to buy. 
According to Rosander (1980), there are five dimensions of service quality: quality of employee performance, facility, data, decision, and outcome. Undoubtedly, the performance of the employee influences customer satisfaction. This phenomenon has been referred to as interactive quality (Lehtinen \& Lehtinen, 1982). Parasuraman, Zeithaml, \& Berry (1985) go so far as to suggest that service quality is ultimately a function of the relationship between the employee and the customer, not the product or the price. Sasser, Olsen, \& Wyckoff (1987) echo the assertion that personnel performance is a critical factor in the satisfaction of customers. If all of them are right, the relationship between satisfaction with quality of work life and customer service attitudes cannot be understated.

\section{Measuring Customer Service Attitudes}

The challenge of measuring service quality has increasingly captured the attention of researchers (Teas, 1994; Cronin \& Taylor, 1992). While the substance and determinants of quality may remain undefined, its importance to organizations is unquestionable. Nevertheless, numerous problems inherent in the measurement of customer service attitudes still exist (Reeves \& Bednar, 1994). Perhaps the complexities involved in measuring this construct have deterred many researchers from attempting to define and model service quality. Maybe this is also the reason why many of the efforts to define and measure service quality have emanated primarily from manufacturing, rather than service, settings.

When it has been measured, quality has sometimes been defined as a "zero defect" policy, a perspective the Japanese have embraced. Alternatively, P.B. Crosby (1979) quantifies quality as "conformance to requirements." Garvin $(1983 ; 1988)$, on the other hand, measures quality in terms of counting the incidence of "intemal failures" and "external failures." Other definitions include "value" (Abbot, 1955; Feigenbaum, 1982), "concordance to specification" (Gilmore, 1974; Levitt, 1972), "fitness for use" (Juran, 1992), "loss avoidance" (Taguchi, cited in Ross, 1989), and "meeting and/or exceeding customers' expectations" (Parasuraman, Zeithaml, \& Berry, 1985). All to say, despite the fact there are numerous conceptualizations, definitions and measurements of quality, a single one may not be adequate for understanding the essence of 
service quality. Furthermore, no one definition of quality is appropriate in every situation (Reeves \& Bednar, 1994), especially in service settings (Parasuraman, Zeithaml, \& Berry, 1985).

As is well known, the differences between manufacturing organizations and service organizations are numerous and profound. According to Parasuraman, Zeithaml, \& Berry (1985), there are three fundamental and well-documented characteristics that make service organizations different from manufacturing ones. First, most services are intangible (Bateson, 1977; Berry, 1980; Lovelock, 1980, 1983; Shostack, 1977). Second, services are heterogeneous (Booms \& Bitner, 1981). Third, the production and consumption of services are inseparable (Carmen \& Langeard, 1980; Gronroos, 1978, Regan, 1963; Upah, 1980). Considering these differences, it is difficult, perhaps even inappropriate, to apply quality management systems derived in manufacturing settings to service operations. Accordingly, this study will focus only on those constructs most relevant in a service setting.

Recently, other researchers have also begun to isolate and explore the issue of measuring service quality (Teas, 1994; Parasuraman, Zeithaml, \& Berry, 1985). However, arguments about the appropriate dimensions, those that can accurately capture the essence of service quality, persist. According to Cronin \& Taylor (1992), service quality may either be measured in terms of attitudes, such as CSA, or outcomes, like satisfied, or repeat, customers. These two constructs are certainly related, but they are not equivalent (Cronin \& Taylor, 1992). In any event, the overarching principle of TQM, in other words--the predominant endogenous variable, should be "customer-focus" (Parasuraman, Zeithaml, \& Berry, 1985). In recognition of this principle, researchers have proposed several measures of service quality (Parasuraman, Zeithaml, \& Berry, 1985, 1988; Parasuraman, Berry, \& Zeithaml, 1991, 1993; Williams \& Zigli, 1987; Sasser, Olsen, \& Wycoff, 1987). For example, Parasuraman, Zeithaml, \& Berry (1985) suggest that the dimensions of service quality encompass: reliability, credibility, security, tangible, access, communication, competence, courtesy, responsiveness, and understand/knowing. Others, such as Williams \& Zigli (1987) and Sasser, Olsen, \& Wycoff (1987), offer similar dimensions of service quality. 
After reviewing the aforementioned studies, it is apparent that researchers still lack a solid theoretical framework to describe and empirically examine service quality (Cronin \& Taylor, 1992; Garvin, 1988; Carman, 1990). Based on the widely accepted systematic perspective, the input-throughput-output model (Katz \& Kahn, 1978), the present study uses customer service attitudes (CSA) as its measure of service quality. In doing so, we posit that there are four dimensions that make up customer service attitudes. They include: the "input dimension," for example, knowledge of and confidence in the product (Leigh \& McGraw, 1989; Brown, 1991; Deming, 1986; Juran, 1989; M. Walton, 1986; Dobbins, Cardy, \& Carson, 1991); the "throughput dimension," such as, friendly interaction with customers, good communications, and attention to customers; the "output dimension," encompassing, patience with customers and resolving problems for customers; and the "contextual dimension," addressing the employee's appearance, work environment, and responsiveness. All four of these dimensions, and variable chosen to represent them, are externalized signals employees send to customers about their job. Figure 1 depicts the systematic framework for service quality that the current study ascribes to.

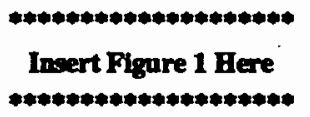

\section{Quality of Work Life (QWL)}

The notion of QWL as we now know it has been the subject of inquiry since the early 1960s. Before this, QWL was, to some degree, addressed under the themes of scientific management, human relations, and job design. Although they have not shared a common nomenclature, the principles of QWL that have been embedded in each of these perspectives are quite similar. Indeed, there is little doubt that QWL has the potential to affect labor relations and human relations in organizational settings. However, when it comes to QWL, few well developed and theoretical perspectives exist. Hence, there are many, related, but different definitions of and frameworks for QWL (Eilon, 1976; Lawler, 1975; R. Walton, 1975; Taylor, 1978). 
Despite these differences, it is widely believed that QWL significantly increases desirable employee outcomes, such as job satisfaction and organizational commitment. In fact, QWL has been shown to be related to improved organizational performance (Katz, Kochan, Gobeille, 1983). Moreover, it has been shown to reduce many dysfunctional behaviors (Havlovic, 1991) including: absenteeism (Lawler, 1986; Scobel, 1975; Ronchi \& Wilken, 1977; Goodman, 1980), work accidents (Macy, 1980; Goodman, 1979), grievances (Ronchi, 1981; Macy, 1980, Straw \& Heckscher, 1984; Eaton, Gordon, Keefe, 1992), and turnover (Lawler, 1986; Scobel, 1975; Macy \& Mirvis, 1976; Goodman, 1980).

As has been the case for TQM, it is plausible to argue that some of the most insightful contributions on QWL have more of a practitioner basis than an academic one (Stepp, 1985; Macy, 1980; Straw \& Heckscher, 1984; Shamir \& Salomon, 1985; Ackoff \& Deane, 1984; Lawler, 1986; Marshall, 1987; Stein, 1983; Voos, 1989).

To summarize, since the early 1970 's, when the first comprehensive QWL bibliography was developed (Taylor, Landy, Levine, \& Kamath, 1973), there have been numerous frameworks to describe QWL, and the managerial practices that affect it (Davis \& Cherns, 1975; Biderman \& Drury, 1976). In almost all of these cases, though, the emphasis has been on being "employeefocused."

\section{Measuring Quality of Work Life}

Not surprisingly, there are nearly as many measures for QWL as there are conceptualizations of it (Levine, Taylor, \& Davis, 1984). Not surprisingly, there is only minimal consistency and standardization among researchers studying this phenomenon (Golembiewski \& Sun, 1990). In the present study, we blend select concepts found in rewards theory and motivation theory with findings from previous studies (Efraty \& Sirgy, 1990; Weiner, 1980; Lawler, 1973; Dyer \& Parker, 1975; Weitz, Sujan, \& Sujan, 1986), to develop a new, more comprehensive set of dimensions for QWL.

As noted, QWL is believed to play a major role in guiding work behavior (Weiner, 1980). Historically, it has usually been conceptualized as having two dimensions at most, intrinsic QWL 
and extrinsic QWL (Lawler, 1973). With regard to the intrinsic dimension of QWL, Dyer and Parker (1975) proposed that employee assessments relate to the task or job itself. Alternatively, the extrinsic dimension of QWL has been thought to be a function of environmental factors in the work setting that go beyond tasks and duties. According to this typology, the level of intrinsic QWL in a service setting will largely be a function of the degree to which employees find their work or tasks to be inherently interesting and self satisfying. On the other hand, extrinsic QWL will be associated with the extent to which work serves as a means for obtaining tangible rewards, such as money, benefits, and formal recognition (Switzky \& Haywood, 1974).

Keep in mind, however, that a distinguishing and important characteristic of service settings is that employees frequently have direct contact with other people, customers. In this setting, the intrinsic-extrinsic framework is insufficient to describe QWL in service settings. Hence, we turn to the Existence-Relatedness-Growth (ERG) model (Alderfer, 1972) and borrow an additional construct to develop a more comprehensive conceptualization of QWL (see Figure 2). Applying this model, existence needs may be thought of as physiological and material desires. In organizational settings, the need for pay, benefits, and physical conditions fall into this category. Next, relatedness needs include those that involve interpersonal relationships with others in working settings. Finally, growth needs are those needs that involve a person's efforts toward creative or personal growth on the job.

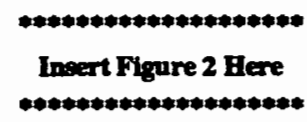

Under the ERG model, an employee's initial assessment of QWL will focus on extrinsic rewards (extrinsic QWL). Without a doubt, compensation systems play an important role in the motivation and control of employees. Accordingly, compensation policies and practices are usually the means for delivering for extrinsic QWL. Judgments about the job itself and performance feedback (Hammmond, McClelland, \& Mumpower, 1980; Jacoby, Mazursky, Troutman, \& Kuss, 1984) are usually present as well (intrinsic QWL). Given these historical 
foci, it is not surprising that job characteristics (tasks, duties, and pay) have received the most empirical attention when these two dimensions of QWL has been studied (Hackman \& Oldham, 1980).

To the intrinsic and extrinsic dimensions of QWL, this study adds social QWL (Wiggings \& Steade, 1976; Salancik \& Pfeffer, 1978). Essentially, this dimension reflects an evaluation of employees' relationships, those with supervisors, co-workers, and customers (social QWL). By including this, previously unexplored, dimension of QWL a more complete conceptualization and evaluation of QWL is possible.

\section{The Relationship Between QWL and CSA}

In the service sector, the effectiveness of an organization is determined in large part by the quality of the interactions that take place between employees and customers. Quite simply, meeting the expectations of customers is expected to lead to increased sales and profits. Of course, organizations can also meet, indeed create and meet, expectations through other activities, like marketing strategies (pertaining to: products, prices, channels, and promotions). Whatever the strategy, conventional wisdom holds that in order for a company to be successful, the most important factor is having willing, able, and motivated employees who will provide satisfactory customer service. If organizations do not provide acceptable working conditions and work environments, this may diminish employee motivation and eliminate the incentives to serve and satisfy customers. Moreover, it will be difficult for employees to maintain long-term relationships with customers if they do not enjoy mutually edifying relationships with their co-workers, supervisors, and customers. Figure 3 depicts the interdependent relationships that exist between the organization, its employees, and its customers.

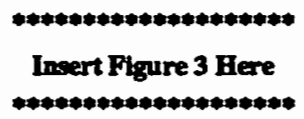

Recall that customer service attitudes are manifest in the form of external employee signals and quality of work life assessments are internal employee evaluations about their work, rewards, and relationships. Given this theoretical backdrop, we hypothesize the following: 
Hypothesis 1: There will be a positive relationship between intrinsic quality of work life and the four dimensions of customer service attitudes.

Hypothesis 2: There will be a positive relationship between extrinsic quality of work life and the four dimensions of customer service attitudes.

Hypothesis 3: There will be a positive relationship between social quality of work life and the four dimensions of customer service attitudes.

In the past, the main setting in which research into customer service quality has been conducted has been in the procurement of tangible goods in single occurrence transactions, and the role of employees in multiple-interaction service contexts has received limited attention (Crosby, Evans, \& Cowles, 1990). This is the case even though most service exchanges involve repetitive, if not continual, streams of interactions between employees and customers over time (Lovelock, 1983). In recent years, however, the customer service literature has increasingly addressed the importance of these interactions in creating satisfied customers (Crosby \& Stephens, 1987; Parasuraman, Zeithaml, \& Berry, 1985; Solomon, Suprenant, Czepiel, \& Gutman, 1985). In these encounters between employees and customers, this form of service quality has been proposed to be a precursor to relationship quality (Crosby, 1989).

Relational selling refers to the behaviors undertaken by service employees to strengthen long-term organization-customer loyalties. The extent to which these behaviors positively influence this relationship depends in large part on the attitudes employees exhibit towards customers (Porter, Steers, Mowday, \& Boulian, 1974). Indeed, the effort to nurture customer relationships has been identified by many as a key determinant of long-term customer loyalty in the service sector (Crosby, 1984; Greenwich Associates, 1987).

Recently, the relationships between organizational commitment and job involvement and QWL have also been examined, in sales and other related settings (Futrell \& Parasuraman, 1984; Field \& Thacker, 1992; Bluedoren, 1980; Locke, 1976; Mobley et al., 1979; Mobley, 1982a, 1982b; Steers, 1977; Steers \& Porter, 1983). Several of these studies have reported a small, negative correlation between QWL and turnover, an indicator of organizational commitment. To 
examine this relationship, between QWL and organizational commitment, models of withdrawal for the turnover process have also been developed (Bluedoren, 1980; Forrest, Cummings, \& Johnson, 1977; Locke, 1976; Mobley, 1977; Porter \& Steers, 1973; Price, 1977). In these models, QWL is the explanatory variable used to predict an employee's intention to quit, intention to search for a new job, and shirking on the job.

As noted, although a few recent studies have examined the association between QWL and the likelihood of quitting--a measure of organizational commitment (Parasuraman \& Futrell, 1983); the relationship between QWL and job involvement has been virtually ignored in service settings. Recently, though, the relationship between employee effort, which is somewhat related to job involvement and organizational commitment, and satisfaction; which is somewhat related to QWL was explored; and a positive relationship was been found (Brown \& Peterson, 1994).

In summary, $Q W L$ deficiencies seem to reduce employees' commitment to their organizations, seen in their intention to quit; their jobs, evident as shirking or freeloading; and their customers, manifest as substandard customer service attitudes (Porter, Steers, Mowday, \& Boulian, 1974; Mitchell, 1979). In addition, high commitment and high involvement are hypothesized to be positively correlated with favorable customer service attitudes (Aderson, Rungtusanatham, \& Schroeder, 1994; Deming, 1986; Hackman, Oldham, Jason, \& Purdy, 1975).

In the current study, we examine a number of relationships between QWL (extrinsic, intrinsic, \& social), job involvement, organizational commitment, and CSA, customer service attitudes. Figure 4 shows the research framework that under girds this study. To reiterate, low organization commitment and low job involvement are expected to result in inferior customer service attitudes

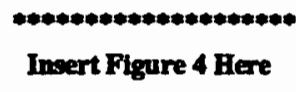

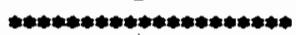


In accordance with the theoretical perspectives discussed previously and the limited findings to date, we hypothesize the following:

Hypothesis 4: There will be a positive relationship between organizational commitment and the four dimensions of customer service attitudes.

Hypothesis 5: There will be a positive relationship between job involvement and the four dimensions of customer service attitudes.

As outlined previously, there is some reason to believe that job involvement and organizational commitment may mediate the effects that the three dimensions of QWL (extrinsic, intrinsic, and social) have on customer service attitudes. In short, being committed to one's job or organization may offset dissatisfaction with or supersede satisfaction with one's rewards, work, or relationships. Therefore,

Hypothesis 6: Organizational commitment will mediate the strength of the relationships between quality of work life and customer service attitudes.

Hypothesis 7: Job Involvement will mediate the strength of the relationships between quality of work life and customer service attitudes.

\section{Data Measures, and Methods}

\section{Data}

The sample for the present study was collected from department store, convenience store, restaurant, and fast-food store employees in Taiwan. Because we collected the responses through personal interviews, our response rate was quite high. Of the 500 questionnaires sent, we were able to schedule follow-up meetings with $\mathbf{4 0 2}$ people, or $\mathbf{8 0 . 4 \%}$. After complete or abbreviated interviews, ten of the these questionnaires were deemed usable. Therefore, there was an effective response rate of 392 persons (78.4\%). The response rate by industry was as follows: Department stores, 128 of $140(85.7 \%)$; convenience stores, 81 of $120(67.5 \%)$; restaurants, 91 of 120 (75.8\%); and fast-food, 92 of $120(76.7 \%)$. 


\section{Measures}

\section{Dependent Variables}

Customer Service Attitudes. The measure of customer service attitudes, which was based on Parasuraman, Zeithaml, \& Berry (1985), is divided into four dimensions (see Appendix 1). The input dimension includes items tapping knowledge of and confidence in the product. There are six items for this dimension, and the Cronbach alpha is 0.69 . The throughput dimension includes four items about friendliness, communication skills, and attention to customers. Its Cronbach alpha is .68. The output dimension includes four items, two pertaining to patience with customers and two regarding solving problems for customers. The reliability for this dimension is 0.71 . The contextual dimension is made up of seven items assessing the service setting (including attire, environment, and courtesy). Its Cronbach alpha is 0.81. For each of the four dimensions of CSA, a six-point Likert scale was used.

\section{Explanatory Variables}

Quality of Working Life. The measure of quality of working life, which was based on Levin et al. (1984) and Hackman \& Oldham (1980), is divided into two conventional constructs: intrinsic and extrinsic, and a new one, social (see Appendix 2). Intrinsic QWL taps the degree of satisfaction with the job itself and related factors. The items include: participation ( 3 items), promotion ( 3 items), skill-learning ( 1 item), self-esteems ( 2 items), and job characteristics (5 items: skill variety, task identity, task significance, autonomy, and feedback). In total, there are 14 indicators for this dimension, and its Cronbach alpha is $\mathbf{0 . 8 8}$. The second dimension, extrinsic QWL, has 8 items. They include the reward system ( 3 items), the benefits program ( 3 items), and job stability ( 2 items). Cronbach alpha for this variable was $\mathbf{0 . 8 2}$. The last dimension is social QWL. This dimension focuses on supervisor, coworker, and customer relationships. Comprised of ten items, it addresses is broken down as follows: supervisors ( 3 items), coworkers (4 items), and customer ( 3 items). The Cronbach alpha is 0.91 . For each dimension of QWL, a six-point scale ranging from 1 , strong disagree, to 6 , strongly agree, was used. 


\section{Mediating Variables}

Organization Commitment. Our measure of organizational commitment, which was based on Porter, Steers, Mowday, \& Boulian (1970), was obtained using a consolidated scale consisting of four items. Each was measured on a six-point scale. These attitudinal organizational commitment indicators include: willingness to help the organization to be successful, willingness to accept any task assigned by the company, being proud to be a member of the company, and concern for the future of company. The Cronbach alpha for this variable is 0.91 .

Job Involvement. Our measure of job involvement used in this study was based on the work of Farrell \& Rusbult (1981) and its Cronbach alpha is 0.87. The five items we used were: expending extra effort during off-work time, caring about the work even in non-work time, setting job goals for oneself, engaging in more one task simultaneously, and setting high standards and goals.

\section{Methods}

Following the procedure for analyzing the effects of mediators suggested by Cohen $\&$ Cohen (1983), we performed multiple regression analysis to examine the relationships between quality of work life and customer service attitudes (see, for example, Parasuraman, Greenhaus, Rabinowitz, Bedeian, \& Mossholder, 1989). First, the three dimensions of QWL (extrinsic, intrinsic, and social) were regressed on a dimension of total quality management. In the next step, the two mediating variables (organizational commitment and job involvement) were included, one at a time. This enables their individual effects on that dimension to be isolated and tested. If the relationship between any dimension of QWL and CSA was substantially changed by the addition of either of the two hypothesized mediators, we can conclude that it plays a mediating role. 


\section{RESULTS}

\section{Intercorrelations}

The means, standard deviations, coefficient alphas, and intercorrelations for the dependent, independent, and mediating variables may be found in Table 1. The alphas indicate internal consistency. Note that the reliabilities for input and throughput CSA were somewhat lower than the conventional 0.70 level (Nunnally, 1978). They were, however, extremely close to that level (0.68 and 0.69). As expected, all of the first order correlations between QWL and CSA were positive and significant (min.: $r=.12$, max.: $r=.45$, mean $r=.28$ ).

Regarding the proposed mediators, intrinsic QWL had a positive relationship with organizational commitment $(r=.23, p<.01)$ and job involvement $(r=.57, p<.01)$. Thus, making the work itself rewarding seems to engender more commitment to the organization and increased job involvement. Likewise, extrinsic QWL had a positive relationship with organizational commitment $(r=.22, p<.01)$ and job involvement $(r=.41, p<.01)$. So, the provision of tangible rewards has a positive association with organizational commitment and job involvement. Finally, social QWL had a positive relationship with organizational commitment $(r=.41, p<.01)$ and job involvement $(r=.49, p<01)$. That is to say, improving the social setting and social relations is associated with increased employee commitment to the organization and more job involvement.

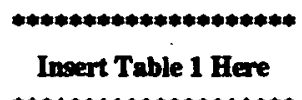

The Mediating Effects of Organizational Commitment and Job Involvement on CSA CSA--input

Table 2 shows the regression results for the input dimension of customer service attitudes. As far as the direct effects of QWL on this dimension of CSA are concerned, only social QWL had a significant positive effect on CSA--input. This finding provides partial support for $\mathrm{H}_{3}$ and no support for $\mathrm{H}_{1}$ and $\mathrm{H}_{2}$. After either mediator is added, note that both organizational commitment $(b=.35, p<.001)$ and job involvement $(b=.13, p<.01)$ were positively related to CSA- 
-input, providing some evidence for $\mathrm{H}_{4}$ and $\mathrm{H}_{5}$. Contrary to $\mathrm{H}_{6}$ and $\mathrm{H}_{7}$, however, when either of the mediating variables (organizational commitment and job involvement) were added, the regression coefficient for social QWL, though reduced, remained significant.

\section{CSA--throughput}

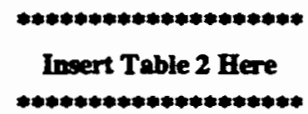

Turning to Table 3, observe that intrinsic QWL and social QWL both induce significant initial effects for the throughput dimension of customer service attitudes. These findings provide some support for $\mathrm{H}_{1}$ and $\mathrm{H}_{3}$. Again, both organizational commitment $(b=.26, p<.001)$ and job involvement $(b=.25, p<.001)$ have positive direct effects on CSA--throughput providing some confirmation for $\mathrm{H}_{4}$ and $\mathrm{H}_{5}$ :

With respect to their roles as mediators, observe that when organizational commitment is included, the effect of social QWL reduces to non-significance (from $b=.34, p<.001$ to $b=.17$, p>.05). This indicates that the effect of social QWL on the throughput dimension of customer service attitudes is mediated by organizational commitment. In addition, the direct effect of intrinsic QWL reduces to non significance when job involvement is added (from $b=.26, p<.001$ to $\mathrm{b}=-.10, \mathrm{p}>.05)$. Therefore, the relationship between intrinsic QWL and CSA--throughput is mediated by job involvement. Hence, for this dimension of CSA, there is some evidence for $\mathrm{H}_{6}$ and $\mathrm{H}_{7}$, which hold that organizational commitment and job involvement will mediate the relationship between QWL and CSA.

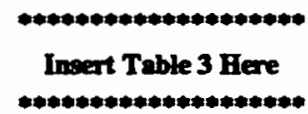

\section{CSA--output}

As may be seen in Table 4, only intrinsic QWL is observed to have a significant effect on the output dimension of customer service attitudes. Once more, this finding confirms $\mathrm{H}_{1}$. For this dimension of CSA, job involvement $(b=.43, p<.01)$, but not organizational commitment $(b=$ $.09, \mathrm{p}>.05$ ), is positively related to CSA-output. This result lends support to $\mathrm{H}_{5}$, but, given that there is not a direct effect for organizational commitment, $\mathrm{H}_{4}$ is not confirmed here. 
Note also that the direct effect of intrinsic QWL reduces to non-significance when job involvement is included as a mediator $(b=.33, p<.001$ to $b=.06, p>.05)$. This provides further evidence for $\mathrm{H}_{7}$, which proposes that job involvement mediates the relationship between quality of work life and customer service attitudes. Organizational commitment does not act as a mediator in this case, so $\mathrm{H}_{6}$ is not confirmed here.

\section{CSA--contextual}

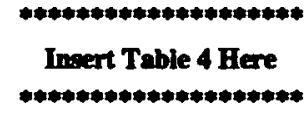

As may be seen in Table 5, as was the case for CSA--throughput, intrinsic QWL and social QWL have a direct, positive effect on the contextual dimension of $\mathrm{CSA}(\mathrm{b}=.23, \mathrm{p}<.001$ and $b=.18, p<.01$ ). These findings provide further evidence for $H_{1}$ and $\mathrm{H}_{3}$.

When organizational commitment is added as a mediator the effect of intrinsic QWL remains significant (from $b=.23, p<.001$ to $b=.23, p<.001$ ), but the effect of social $Q W L$ diminishes to non significance (from $b=.18, p<.01$ to $b=.15, p>.05$ ). Note, also, that organizational commitment does not have a direct effect on CSA--contextual. Thus, there is no evidence here for $\mathrm{H}_{4}$. When the second mediating variable, job involvement, is included, both intrinsic QWL (from $b=.23, p<.01$ to $b=-.09, p>.05$ ) and social $Q W L$ (from .18, $p<.01$ to $b=.12$, p>.05) reduce to non significance. Therefore, the results for CSA--contextual provide some additional evidence for $\mathrm{H}_{6}$ and $\mathrm{H}_{7}$, which specify that organizational commitment and job involvement will mediate the relationship between QWL and CSA. 


\section{CONCLUSIONS AND IMPLICATIONS FOR FUTURE RESEARCH}

In the current study, we find some of the first empirical evidence for a relationship between quality of work-life (QWL) and customer service attitudes (CSA). Moreover, we also find that under certain conditions organizational commitment and job involvement mediate the strength of the relationship between QWL and CSA.

More specifically, intrinsic QWL had a direct effect on three of the four dimensions of CSA (throughput, output, contextual). This provides partial support for $\mathrm{H}_{1}$, which holds that people who are satisfied with the tasks and duties of their work will have better attitudes towards customers. Social QWL was also observed to have a direct effect on three dimensions of CSA (input, throughput, contextual). So $\mathrm{H}_{3}$, the assertion that having better relationships and working in more desirable settings will have better customer service attitudes, is partially confirmed. Given these findings, it appears that employees' customer service attitudes, and, presumably, subsequent service quality can be increased by improving the intrinsic and social quality of work life of employees.

In this study, however, we found that the extrinsic dimension of QWL was not strongly related to customer service attitudes. Thus $\mathrm{H}_{2}$, was not even partially confirmed. To the contrary, we found that intrinsic and social QWL had the greatest effect on customer service attitudes. According to Herzberg Mausner, \& Snyderman (1954), extrinsic compensation may be a type of hygiene factor, but not a motivating factor. To be sure, we do not deny the importance

of reward systems for service quality, but based upon the results in this research, what we suggest is that more attention should be given to the non-remunerative dimensions of reward systems to increase the well-being of employees. In turn, this should engender improved customer service attitudes and eventually translate into increased customer satisfaction.

All else equal, organizational commitment was observed to have a direct impact on customer service attitudes when it was added to the model. It had positive relationships with two of the four dimensions of CSA (input, and throughput). Therefore, $\mathrm{H}_{4}$ is partially confirmed. The more committed a person is to their organization, the better will be their customer service 
attitudes towards confidently introducing themselves and their products. Strong and positive associations between job involvement and all four of the dimensions of CSA (imput, throughput, output, and contextual) were detected. Hence $\mathrm{H}_{5}$, which holds that job involvement and customer service attitudes will be positively related, received the strongest support of any of the explanatory variables.

The results of this study also demonstrate that organizational commitment and job involvement have mediating effects on the relationships between QWL and CSA. Organizational commitment was observed to play a mediating role in two of the six instances where direct effects between QWL and CSA were originally found. Accordingly, there is partial support for $\mathrm{H}_{6}$. In addition, for four of the six cases where initial direct effects were observed, job involvement meditated these effects between QWL and CSA. Consequently, there is even stronger support for $\mathrm{H}_{7}$.

In summary, the results support the two basic propositions of this research study: quality of work life has a positive effect on customer service attitudes, and organizational commitment and job involvement mediate this relationship. As stated previously, there has not been an empirical investigation to test these propositions to date, although, the role of employee satisfaction on customer service attitudes and quality has been referred to frequently (Cortada, 1993).

Prescriptively speaking, it appears that service organizations should strive to increase organizational commitment and job involvement. It certainly seems intuitive that employees who have strong organizational commitment and job involvement will devote themselves to nurturing relationships with customers and providing them with superior service. Undoubtedly, this can be facilitated through the introduction and implementation of improved human resource processes.

Though there are some noteworthy contributions in the present study, some issues related to it constrain the interpretation of its findings and suggest new directions for further research. For example, as noted, we use customer service attitudes as indicators of service quality. The inherent assumption is that the customer service attitudes will be strongly related to service 
delivery, purchasing decisions, and customer satisfaction. Of course, there are numerous other factors that can influence customer satisfaction; and customer service attitudes are but one of these influential factors. Further research should test the link between customer service attitudes and these other outcomes to more precisely quantify their relationships.

A second and related limitation is that we emphasize a human resource management perspective when examining service quality. The main point here is that an organization can improve customer service and satisfaction through means other than increasing the quality of work life of its employees. Obviously, QWL is not the only means by which customer service can be improved. For example, product quality, the physical plant, and marketing strategies (with regard to: products, prices, and promotions) can also influence customer service. Therefore, it may be useful for researchers to investigate the interactions between human resource management outcomes, like QWL, and business outcomes besides customer service attitudes, like service delivery, purchasing decisions, and customer satisfaction.

Finally, the measurement of customer service attitudes itself merits future attention. In this study, we developed a tentative theoretical framework and a set of measures to study this construct and its different dimensions. Other researchers might attempt to use different methods to confirm this scheme or obtain even more valid and reliable measurements.

In the end, this study has several important implications for academics and practitioners. As mentioned, there are but a few empirical studies that focus on the relationship between human resource management system outcomes, like employee assessments of their quality of work life, and total quality management outcomes, in the form of customer service attitudes. Naturally; we believe that human resource management has an important role in total quality management, especially in service settings. While the QWL-TQM issue has frequently been addressed conceptually and pragmatically, there is still too little research evidence on this topic. Indeed, as total quality management practices have proliferated, there is little doubt that human resource management interventions are increasingly linked to quality management initiatives. The spread of semiautonomous work teams is but one example. 
Without a doubt, the psychological implications and human factors inherent in these TQM activities must also be understood to ensure their successful implementation. For example, the need to improve employees' relationships with coworkers highlights the importance of social QWL. Among others, there is a need for communications skills training. Likewise, managing relationships with supervisors raises issues of leadership and control. Job design and performance feedback are also undeniably important to intrinsic QWL and service quality. Finally, human resource management activities in service settings have, and will continue to, focus on reward systems, commissions, and performance evaluations (Eisenhardt, 1988), which affect extrinsic QWL.

To summarize, an increasing number of authors have argued that human resource management practices should be closely aligned with the principles and processes of total quality management. Focusing on total quality management represents a shift from a individual performance and attitudinal assessments to more of an organizational performance and collective fulfillment perceptive. The findings in this study should be useful for both human resource management and total quality management adherents. In addition, further examinations into how QWL and CSA intersect are sure to provide many more insights into these ever-evolving fields of study. 


\section{REFERENCES}

Abbott, L. 1955. Quality and competition. New York: Columbia University Press.

Ackoff, R. L., \& Deane, W. B. 1984. The revitalization of Alcoa's Tennessee Operations. National Productivity Review, 3, 239-245.

Alderfer, C. P. 1972. Existence, relatedness, and growth. New York: Free Press.

Anderson, J. C., Rungtusanatham, M., \& Schroeder, R. G. 1994. A theory of quality management underlying the Deming management method. Academy of Management Review, 19, 472 509.

Bateson, J. E. G. 1977. Do we need service marketing. In Marketing consumer services: New insights. Cambridge, MA: Marketing Science Institute, Report \#77-115.

Berry, L. L. 1980. Services marketing is different. Business, 30 (May-June), 24-28.

Bluedoren, A.C. (1980). A unified model of turnover from organizations. Paper presented at the 40th annual meeting of the Academy of Management, Detroit, MI.

Biderman, A. D., \& Drury, F. F. (Eds.). 1976. Measuring work quality for social reporting. New York: Halsted Press.

Booms, B. H., \& Bitner, M. J. 1981. Marketing strategies and organization structures for services firms. In J. Donnelly, \& W. George, (Eds.). Marketing of services, 47-51. Chicago: American Marketing.

Brown, M. G. 1991. Baldrige award-winning quality. White Plains, NY: Quality Resources.

Brown, S. P., \& Peterson, R. A. 1994. The effect of effort on sales performance and job satisfaction. Journal of Marketing, 58 (April), 70-80.

Cardy, R. L., \& Dobbins, G. H. 1993. Human resource management in a total quality organizational environment: Shifting from a traditional to a TQHRM approach. Working Paper, Arizona State University, Tempe.

Carman, J. M. 1990. Consumer perceptions of service quality: An assessment of the SERVQUAL dimensions. Journal of Retailing, 66(1), 33-55.

Carmen, J. M., Langeard, E. 1980. Growth strategies of service firms. Strategic Management Journal, 1, 7-22.

Cohen, J. \& Cohen, P. (1983). Applied multiple regression/correlation analysis for the behavioral sciences. Hillsdale, NJ: Erlbaum. 
Cortada, J. W. 1993. TQM for sales and marketing management. New York: McGraw-Hill.

Cronin, J. J., Jr., \& Taylor, S. A. 1992. Measuring service quality: A reexamination and extension. Journal of Marketing, 56 (July), 55-68.

Crosby, L. A. 1984. Consumer attitudes toward whole life insurance (wave 1). Atlanta, Life Office Management Association.

Crosby, L. A. 1989. Building and maintaining quality in the service relationship. In S. W. Brown, \& E. Gummesson, (Eds.). Quality in services. Lexington, MA: Lexington Books.

Crosby, L. A., Evans, K. R., \& Cowles, D. 1990. Relationship quality in services selling: an interpersonal influence perspective. Joumal of Marketing, 54 (July), 68-81.

Crosby, L. A., \& Stephen, N. 1987. Effects of relationship marketing on satisfaction, retention, and price in the life insurance industry. Journal of Marketing Research, 24 (November), 404-4.11.

Crosby, P. B. 1979. Quality is free: The art of making quality certain. New York: New American Library.

Davis, L. E., \& Cherns, A. B. (Eds.). 1975. The Quality of working life: Problems, prospects, and the state of the art. Vol. 1, New York: Free Press.

Dean, J. W., Jr., \& Bowen, D. E. 1994. Management theory and total quality: Improving research and practice through theory development. Academy of Management Review, 19, 392-418.

Deming, W. E. 1986. Out of the crisis. Cambridge: Massachusetts Institute of Technology, Center for Advanced Engineering Study.

Deming, W. E. 1993. The new economics for industry, government, education. Cambridge: Massachusetts Institute of Technology, Center for Advanced Engineering Study.

Dobbins, G. H., Cardy. R. L., \& Carson, K. P. 1991. Examining fundamental assumptions: A contrast of person and system approaches to human resource management. Research in Personnel and Human Resources Management, 3, 1-38.

Dyer, L., \& Parker, D. F. 1975. Classifying outcomes in work motivation research: An examination of intrinsic-extrinsic dichotomy. Joumal of Applied Psychology, 60, 445-458.

Eaton, A. E., Gordon, M. E., \& Keefe, J.H. 1992. The impact of quality of work life programs and grievances system effectiveness on union commitment. Industrial and Labor Relations Review, 45, 591-604. 
Efraty, D., \& Sirgy, M. J. 1990. The effect of quality of working life on employee behavioral responses. Social Indicators Research, 22, 31-47.

Eisenhardt, K. M. (1988). Agency and institutional explanations of compensation in retail sales. Academy of Management Journal, 31, 488-511.

Elion, S. 1976. The quality of working life. Omega, 4, 367-373.

Farrell, D. \& Rusbult, C.E. (1981) Exchange variables as predictors of job satisfaction, job commitment, and turnover. The import of rewards, costs, alternatives, and investments. Organizational Behavior and Human Performance, 28: 78-95.

Feigenbaum, A. V. 1982. Quality and business growth today. Quality Progress, 15, November, 22-25.

Fields, M. W., Thacker, J. W. 1992. Influence of quality of work life on company and union commitment. Academy of Management Journal, 35, 439-450.

Forrest, C. R., Cummings, L. L., \& Johnson, A. C. 1977. Organizational participation: A critique and model. Academy of Management Review, 2, 586-601.

Futrell, C. M., \& Parasuraman, A. 1984. The relationship of satisfaction and performance to salesforce turnover. Journal of Marketing, 48, Fall, 33-40.

Garvin, D. A. 1983. Quality on the line. Harvard Business Review, 61, (September-October), 6573.

Garvin, D. A. 1988. Managing quality: The strategic and competitive edge. New York: Free Press.

Gilmore, H. L. 1974. Product conformances cost. Quality Progress, 7, May, 16-19.

Golembiewski, R. T., Sun, B. 1990. Positive-finding bias in QWL studies: Rigor and outcomes in a large sample. Journal of Management, 16, 665-674.

Goodman, P. S. 1979. Assessing organizational change: the rushton quality of work experiment. New York: Wiley.

Goodman, P. S. 1980. Quality of work life projects in the 1980s. Proceedings of the 1980 spring meeting, Industrial Relations Research Association, 487-494.

Greenwich Associates, 1987, Large corporate banking survey. Greenwich, CT.

Gronroos, C. 1978. A service-oriented approach to marketing of services. European Journal of Marketing, 12, 588-6-1. 
Hackman, J. R., \& Oldham, G. R. 1980. Work redesign. Reading, MA: Addison-Wesley.

Hackman, J. R., Oldham, G. R., Janson, R., \& Purdy, K. 1975. A new strategy for job enrichment. California Management Review, 27(4), 57-71.

Hannon, J. M. \& Sano, Y. 1994 Customer-driven human resource practices in Japan. Human Resource Planning, 17(3),

Hammond, K. R., McClelland, G. H., \& Munpower, J. 1980. Human judgment and decision making: Theory, methods and procedures. New York: Praeger Publishers.

Havlovic, S. J. 1991. Quality of work life and human resource outcomes. Industrial Relations, 30, 469-479.

Herzberg, F., Mausner, B., \& Snyderman, B. 1954. The Motivation to work. New York: John Wiley.

Jacoby, J., Mazursky, D., Troutman, T., \& Kuss, A. 1984. When feedback is ignored: Disutility of outcome feedback. Journal of Applied Psychology, 69, 531-545.

Juran, J. M. 1989. Juran on leadership for quality: An executive handbook. Wilson, CT: Juran Institute.

Juran, J. M. 1992. Juran on quality by design: The new steps for planning quality into goods and services. New York: Free Press.

Katz, D., \& Kahn, R. L. 1978. The social psychology of organization (2nd ed.). New York: Wiley.

Katz, H. C., Kochan, T. A., \& Gobeille, K. R. 1983. Industrial relations performance, economic performance and QWL programs: An interplant analysis. Industrial and Labor Relations Review, 37, 3-17.

Lawler, E. E., III. 1973. Motivation and work organization. Monterey, CA: Brook/Coles.

Lawler, E. E., III. 1975. Measuring the psychological quality of working life: The why and how of it. In L. E. Davis \& A. B. Cherns (Eds.). The Quality of working life: Problems, prospects, and the state of the art. Vol. 1, New York: Free Press.

Lawler, E. E., III. 1986. High-involvement management. San Francisco, CA: Jossey-Bass.

Lehtinen, U., \& Lehtinen, J. R. 1982. Service quality: A study of quality dimensions. Unpublished working paper. Helsinki: Service Management Institute. 
Leigh, T. W., McGraw, P. F. 1989. Mapping the procedural knowledge of industrial sales personnel: A script-theoretic investigation. Journal of Marketing, 53 (January), 16-34.

Levine, M. F., Taylor, J. C., \& Davis, L. E. 1984. Defining quality of working life. Human Relations, 37, 81-104.

Levitt, T. 1972. Production-line approach to service. Harvard Business Review, 50(5), 41-52.

Locke, E. A. 1976. The nature and consequences of job satisfaction. In M. D. Dunnette (ed.). Handbook of industrial and organizational psychology, 1297-1329. Chicago: Rand McNally.

Lovelock, C. H. 1980. Towards a classification of service marketing. In C. Lamb, \& P. Dunne. (Eds.). Theoretical Developments in Marketing, 72-76.

Lovelock, C. H. 1983. Classifying services to gain strategic marketing insights. Journal of Marketing, 47, (Summer), 9-20.

Macy, B. A. 1980. The bolivar quality of work life program: A longitudinal behavioral and performance assessment. Proceedings of the 32nd annual meeting of the Industrial Relations Research Association, 83-93. Madison, WI.

Macy, B. A., \& Mirvis, P. H. 1976. Methodology for assessment of quality of working life and organizational effectiveness in behavioral-economic terms. Administrative Science Quarterly, 21, 212-226.

Marshall, R. 1987. Unheard voices. New York: Basic Books.

Mitchell, T. R. 1979. Organizational behavior. Annual Review of Psychology, 30, 243-281.

Mobley, W. H. 1977. Intermediate linkages in the relationships between job satisfaction and employee turnover. Journal of Applied Psychology, 62, 237-240.

Mobley, W. H. 1982a. Some unanswered questions in turnover and withdrawal research. Academy of Management Review, 7, 111-116.

Mobley, W. H. 1982b. Employee turnover: Causes, consequences, and control. Reading, MA: Addison-Wesley.

Mobley, W. H., Griffeth, R. W., Hand, H. H., \& Meglino, B. M. 1979. Review and conceptual analysis of the employee turnover process. Psychological Bulletin, 86, 493-522.

Nunnally, J. C. 1978. Psychometric theory. New York: McGraw-Hill.

Oliva, T. A., Oliver, R. L., \& MacMillan, I. C. 1992. A catastrophe model for developing service satisfaction strategies. Joumal of Marketing, 56 (July), 83-95. 
Parasuraman, A., Berry, L. L., \& Zeithaml, V. A. 1993. More on improving service quality measurement. Journal of Retailing, 69, 140-147.

Parasuraman, A., Berry, L. L., \& Zeithaml, V. A. 1991. Refinement and reassessment of the SERVQUAL scale. Journal of Retailing, 67, 420-450.

Parasuraman, A., \& Futrell, C. M. 1983. Demographics, job satisfaction, and propensity to leave of industrial salesman. Joumal of Business Research, 11, 33-48.

Parasuraman, A., Zeithaml, V. A., \& Berry, L. L. 1985. A conceptual model of service and its implications for further research. Journal of Marketing, 4 (Fall), 41-50.

Parasuraman, A., Zeithaml, V. A., \& Berry, L. L. 1988. SERVQUAL: A multiple-item scale for measuring consumer perceptions of service quality. Journal of Retailing, 64, 12-37.

Parasuraman, S., Greenhaus, J., Rabinowitz, S., Bedeian, A., \& Mossholder, K. 1989. Work and family variables as mediators of the relationship between wives' employment and husbands' well-being. Academy of Management Journal, 32(1): 185-201.

Porter, L., Steers, R., Mowday, R., Boulian, P. 1974. Organizational commitment, job satisfaction, and turnover among psychiatric technicians. Journal of Applied Psychology, 59, 603-609.

Porter, L., \& Steers, R. 1973. Organizational, work, and personal factors in employee turnover and absenteeism. Psychological Bulletin, 80, 151-176.

Price, J. L. 1977. The study of turnover. Ames, IA: Iowa State University Press.

Reeve, C. A., \& Bednar, D. A. 1994. Defining quality: Alternatives and implications. Academy of Management Review, 19, 419-445.

Regan, W. 1963. The service revolution. Journal of Marketing, 27, July, 57-62.

Reger, R. K., Gustafson, L. T., Demarie, S. M., \& Mullane, J. V. 1994. Reframing the organization: Why implementing total quality is easier said than done. Academy of Management Review, 19, 565-584.

Ronchi, D. 1981. Quality of working life movement. Employee Relations, 3, 2-6.

Ronchi, D., \& Wilken, R. 1977. Productivity in perspective: The view from a refuse team. Unpublished paper. Center for Human Resource Research, Ohio State University.

Rosander, A. C. 1980. Service industry QC-Is the challenge being met. Quality Progress, 13, September, 34-35. 
Ross, P. J. 1989. Taguchi techniques for quality engineering. New York: McGraw-Hill.

Salancik, G. M., \& Pfeffer, J. 1978. A social information processing approach to job attitudes and task design. Administrative Science Quarterly, 23, 521-40.

Sasser, E. W., Olsen, R. P., \& Wyckoff, D. D. 1987. Management of service operations: Text and cases. Boston: Alley \& Bacon Inc.

Scobel, D. N. 1975. Doing away with the factory blues. Harvard Business Review, 53, Nov.Dec., 132-142.

Shamir, B. \& Salomon, I. 1985. Work-at-home and the quality of working life. Academy of Management Review, 10, 455-464.

Shostack, G. L. 1977. Breaking free from product marketing. Journal of Marketing, 41, April, 7380.

Solomon, M. R., Suprenant, C., Czepiel, J. A., \& Gutman, E. G. 1985. A role theory perspective on dyadic-interactions: The service encounter. Joumal of Marketing, 49, (Winter), 99-111.

Spencer, B. A. 1994. Models of organization and total quality management: A comparison and critical evaluation. Academy of Management Review, 19, 446-471.

Steers, R. M. 1977. Antecedents and outcomes of organizational commitment. Administrative Science Quarterly, 22, 45-56.

Steer, R. M., \& Porter, L. W. 1983. Employee commitment to organizations. In R. M. Steers \& L. W. Porter (Eds.). Motivation and work behavior (3 rd ed.), 441-451. New York: McGraw-Hill.

Stein, B. A. 1983. Quality of work life in action managing for effectiveness. New York: American Management Association.

Stepp, J. R. 1985. Promoting productivity. Monthly Labor Review, 108. Sept., 54-55.

Straw, R. J., \& Heckscher, C. C. 1984. QWL: New working relationships in the communication industry. Labor Studies Journal, 8, Win., 261-274.

Switzky, H. N., \& Haywood, H. C. 1974. Motivational Orientation and the relative efficacy of self-monitored and externally imposed reinforcement systems in children. Journal of personality and social psychology, 30, 360-366.

Taylor, J. C. 1978. An empirical examination of the dimension of quality of working life. Omega, $6,153-160$. 
Taylor, J. C., Landy, J., Levine, M. F., \& Kamath, D. R. 1973. The quality of working life: An annotated bibliography [1957-1972]. Los Angeles: Center for organizational Studies, G. S. M, UCLA.

Teas, R. K. 1994. Expectations as a comparison standard in measuring service quality: An assessment of a reassessment. Journal of Marketing, 58 (January), 132-139.

Upah, G. D. 1980. Mass marketing in service retailing: A review and synthesis of major method. Journal of Retailing, 56, fall, 59-76.

Voos, P. B. 1989. The influence of cooperative programs on union-management relations, flexibility, and other labor relations outcomes. Joumal of Labor Research, 10, Win., 261274.

Waldman, D. A. 1994. The contributions of total quality management to a theory of work performance. Academy of Management Review, 19, 510-536.

Walton, M. 1986. The Deming management method. New York: Perigee Books.

Walton, R. 1975. Criteria for quality of working life. In L. E. Davis \& A. B. Cherns (Eds.). The Quality of working life: Problems, prospects, and the state of the art. Vol. 1, New York: Free Press.

Weiner, B. 1980. Human motivation. New York: Holt, Rinehart and Winston, Inc.

Weitz, B. A., Sujan, H., \& Sujan, M. 1986. Knowledge, motivation, and adaptive behavior: A framework for improving selling effectiveness. Journal of Marketing, 50 (October), 174191.

Wiggins, R. L., Steade, R. D. 1976. Job satisfaction as a social concern. Academy of Management Review, 1, 48-55.

Williams, R. H., \& Zigli, R. M. 1987. Ambiguity impedes quality in the service industries. Quality Progress, 20, July, 14-17.• 


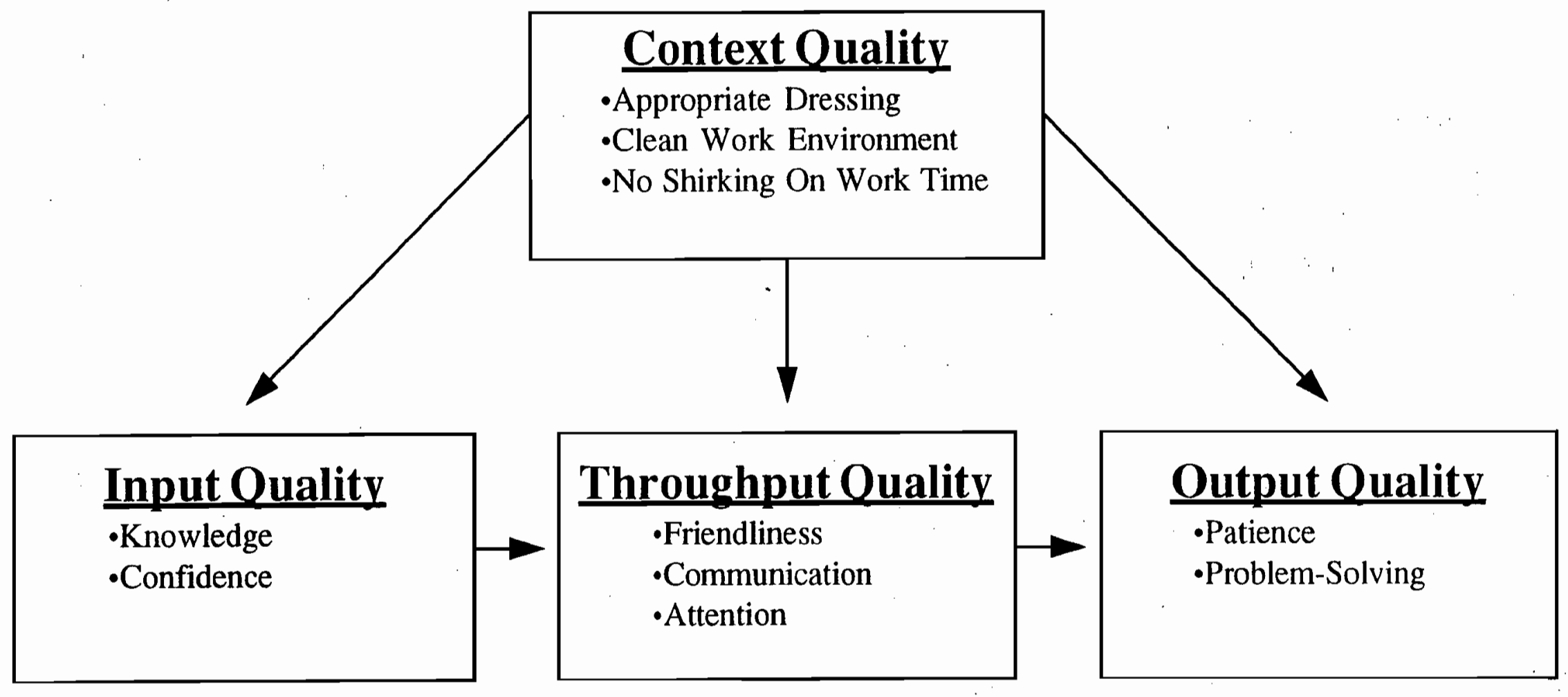

Figure 1: The Measurement System of Service Quality 


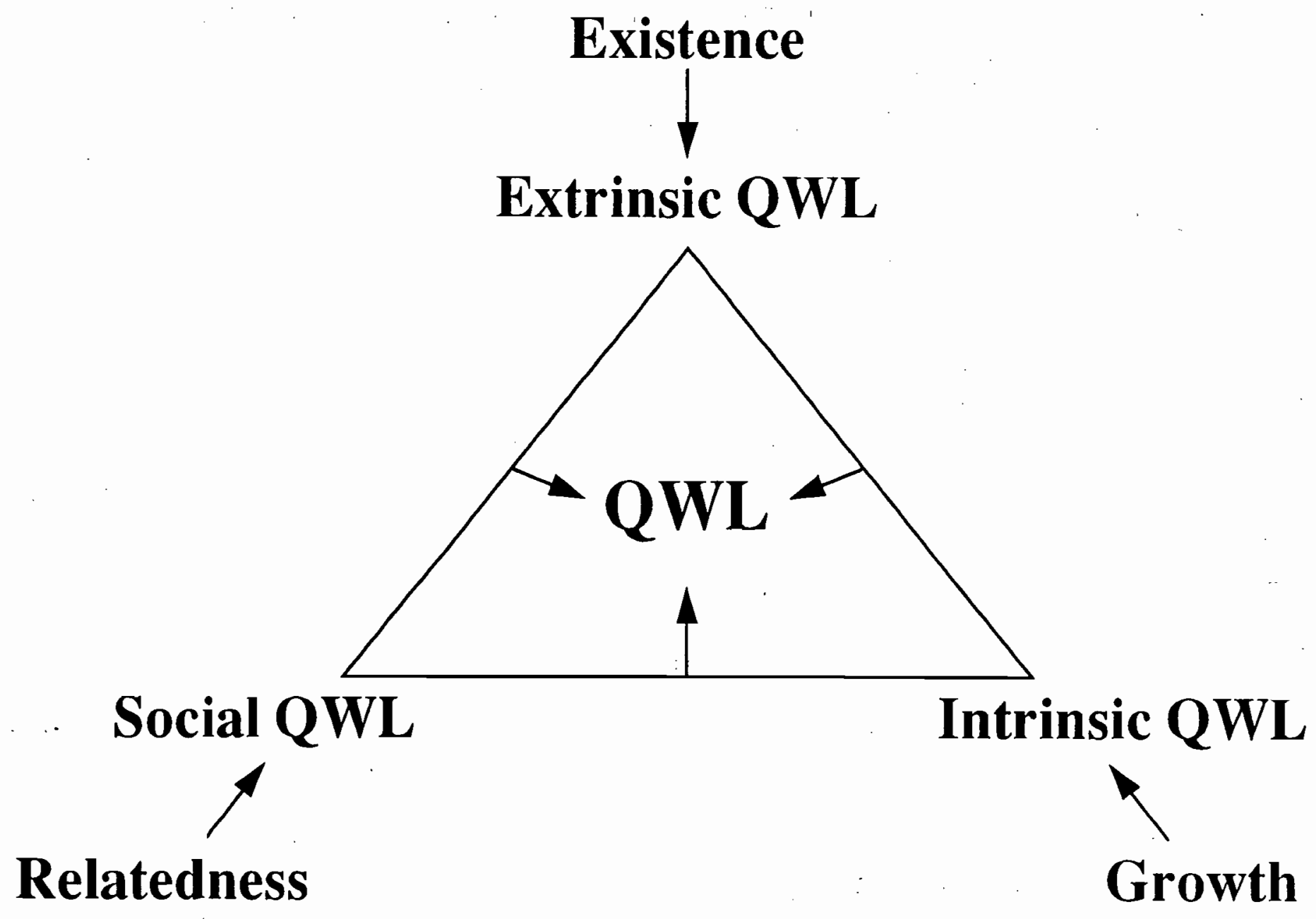

Figure 2: The Measurement System of QWL for Service Settings 


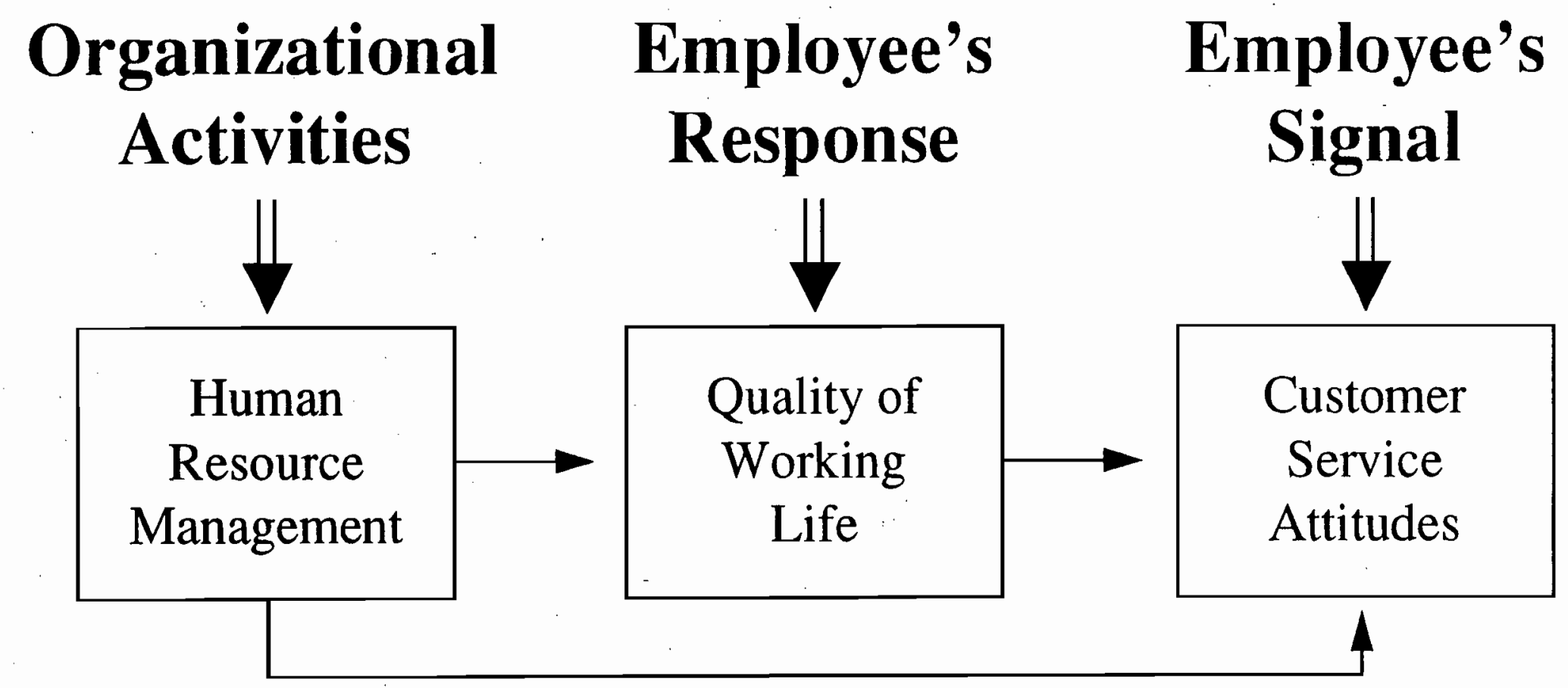

Figure 3: The Organizational Activities, Employee's Response, and Employee's Signal 


\section{Independent Mediating Dependent Variables \\ Variables \\ Variables}

Quality of Work Life

Customer Service Attitude

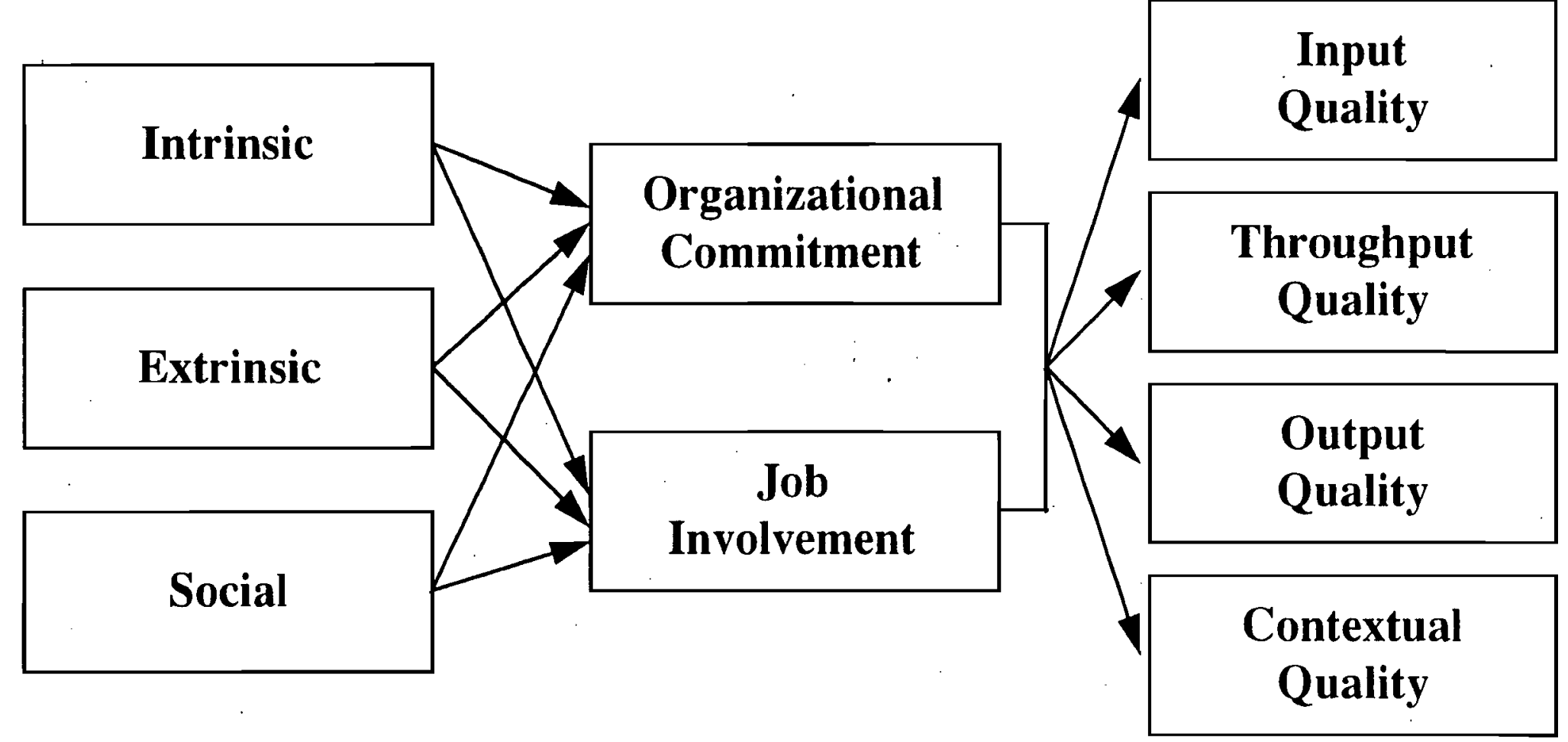

Figure 4: Conceptual Framework 
Table 1: Intercorrelations Among Variables

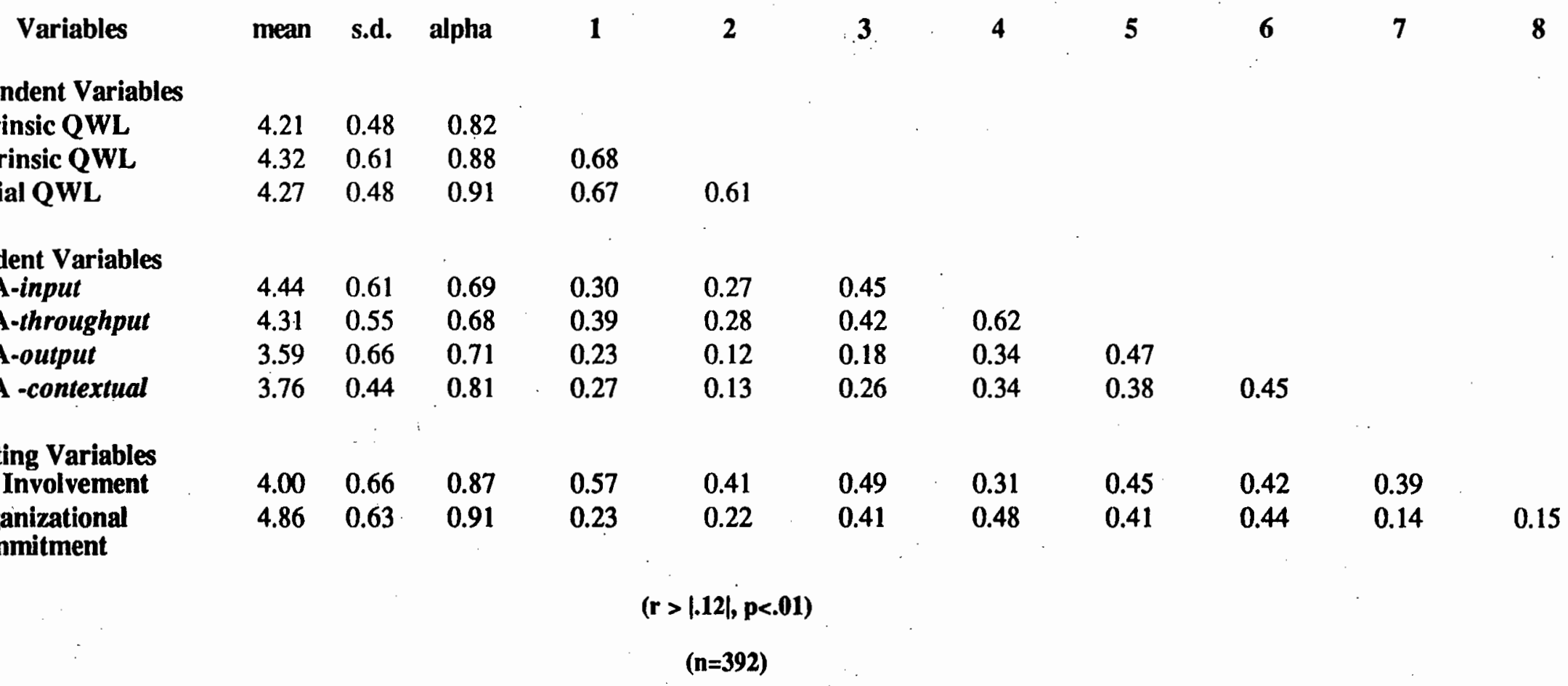




\section{Table 2: Results of Regression Analysis Predicting CSA--input}

Variables

Independent Variables

1. Intrinsic QWL

2. Extrinsic QWL

3. Social QWL

Mediating Variables

4. Organizational Commitment

5. Job Involvement

$\mathbf{R}^{2}$

$\Delta \mathbf{R}^{2}$
Direct Effect

Including
Organizational
Commitment $\quad \begin{gathered}\text { Job } \\ \text { Involvement }\end{gathered}$

0.002

$-0.01$

$0.57 * * *$

0.06

$-0.01$

$0.34 * * *$

0.06

$-0.01$

$0.53^{* * *}$

$0.35 * * *$

$0.20 * * *$

$0.20^{* * *}$
$0.13^{* *}$

0.31

0.11
0.21

0.01

$(* * * p<0.001, * * p<0.01, * p<0.05$, one-tail $)$ $(+++p<0.001,++p<0.01,+p<0.05$, two-tail $)$

$(n=392)$ 
Table 3: Results of Regression Analysis Predicting CSA--throughput

Variables

Independent Variables

1. Intrinsic QWL

2. Extrinsic QWL

3. Social QWL

Mediating Variables

4. Organizational Commitment

5. Job Involvement

$\mathbf{R}^{2}$

$\Delta \mathbf{R}^{2}$
Direct Effect

Organizational

Commitment

Including Mediators

Job Involvement

$0.26 * * *$

$-0.04$

$0.34^{* * *}$

$0.29 * * *$

$-0.04$

0.17

$-0.10$

$-0.04$

$0.27^{* * *}$

$0.26^{* * *}$

$0.25 * * *$

0.20

0.20

0.27

0.07

0.26

0.06

${ }^{* *} p<0.001, * * p<0.01, * p<0.05$, one-tail) $(+++p<0.001,++p<0.01,+p<0.05$, two-tail)

$(n=392)$ 


\section{Table 4: Results of Regression Analysis Predicting CSA--output}

Variables

Direct Effect

Organizational
Commitment

Including Mediators

Job

Involvement

Independent Variables

1. Intrinsic QWL

2. Extrinsic QWL

$0.33^{* * *}$

$-0.09$

3. Social QWL

0.10

$0.34 * * *$

$-0.09$

0.04

0.06

$-0.08$

$-0.01$

Mediating Variables

4. Organizational Commitment

0.09

5. Job Involvement

$\mathbf{R}^{2}$

$\Delta \mathbf{R}^{2}$

$0.43^{* *}$

0.06

0.00
0.18

0.12

$\left({ }^{* * *} p<0.001, * * p<0.01, * p<0.05\right.$, one-tail)

$(+++p<0.001,++p<0.01,+p<0.05$, two-tail)

$(n=392)$ 
Table 5: Results of Regression Analysis Predicting CSA--contextual

Variables

Independent Variables

1. Intrinsic QWL

2. Extrinsic QWL

3. Social QWL

Mediating Variables

4. Organizational Commitment

5. Job Involvement

$$
\mathbf{R}^{2}
$$

$\Delta \mathbf{R}^{2}$

2
Direct Effect

$0.23^{* * *}$

$-0.11$

$0.18^{* *}$

$0.23 * * *$

$-0.11$

0.15

Organizational

Including Mediators

Commitment

Job

Involvement

$-0.09$

$-0.11$

0.12

$\Delta \mathrm{R}$
0.03
$0.10 * * *$
0.10
0.00

$0.22^{* * *}$

0.17

0.07 


\section{APPENDIX 1}

\section{CuSTOMER SERVICE ATtITUdes (CSA)}

\section{CSA-input}

F. I can explain every question about the product. I can help the customers when they have some problems with the product. I have knowledge about the product.

G. I believe our product is the best.

I have confidence in our product.

I have the confidence to provide good service to customers.

\section{CSA-throughput}

H. It is easy to establish friendship with customers.

It is more important to keep good relationships with customers than just selling the product.

I. I always listen to the customer's opinions.

J. I always try to remember the customer's name.

\section{CSA-output}

A. I care for customer's feelings.

I try to help every customer no matter how busy I am.

B. I answer the questions about the products. I help customers find the product.

\section{CSA-contextual}

C. I keep my attire clean.

I keep myself looking good.

D. I keep the workplace clean before the customers come. I keep the products in the proper place.

I keep the workplace clean when customers are leaving.

E. I do not talk with co-workers when customers are coming. I do not criticize the customers when they are leaving. 


\section{OUALITY OF WORK LIFE (OWL)}

\section{APPENDIX 2}

Intrinsic QWL

A. The company is glad to let us express our opinions. The company will let us participate in the decision.

The company offers many channels to let us express opinions.

B. Promotion decisions are fair.

Every employee has equal opportunity to get a promotion.

I believe I will get a promotion if I perform well.

C. I can leam a lot from my job.

The company offers some useful training programs to me.

I believe I can learn a lot from this company.

D. I feel my job is very important from the viewpoint of the company.

I feel my job is respected by those outside the company.

E. My job involves doing the whole piece of work.

I must use a variety of skills and talents to do the job.

I feel my job is very important.

My supervisor will let me know how well I am doing on my job.

I have the chance that permits me to decide on my own job.

\section{Extrinsic OWL}

F. As far as my contribution is concerned, my pay is fair.

As far as my need is concerned, my pay is quite enough. I am satisfied with my pay.

G. I am satisfied with my benefits.

The company offers some useful benefit programs.

The company takes care of my personal problems.

H. My job is very stable (i.e., I'm not afraid of being fired).

The company will not fire the employee without a good reason.

\section{Social OWL}

I. I trust my supervisor.

My supervisor always takes are of my personal problems.

My supervisor is very friendly.

J. I establish good relationships with my co-workers.

The peers will help each other.

My co-workers are just like my family.

It is interesting when I work with my peers.

K. I establish a good relationship with customers.

I talk to the customers just like a friend.

Because of my job, I make friendships with customers. 
No. 93-101 Gordon M. Phillips, Robert J. Weiner

"Information and Normal Backwardation as Determinants of Trading Performance: Evidence from the North-Sea Oil Forward Market." 1994. The Economic_Journal.

No. 93-102 Stephen R. Goldberg, Frank L. Heflin

"The Association Between the Level of International Diversification and Risk"

No. 93-103 John A. Carison

"Risk Aversion, Foreign Exchange Speculation and Gambler's Ruin"

No. 93-104 John A. Carlson, Aasim M. Husain, Jeffrey A. Zimmerman

"Penalties and Exclusion in the Rescheduling and Forgiveness of International Loans"

No. 93-105 Kent D. Miller

"Industry and Country Effects on Manager's Perceptions of Environmental Uncertainties."

1993. Journal of International Business Studies, 24: 693-714.

No. 93-106 Stephen R. Goldberg and Joseph H. Godwin

"Foreign Currency Translation Under Two Cases-Integrated and Isolated Economies"

No. 93-107 Kent D. Miller

"A Comparison of Managers' Uncertainty Perceptions and Country Risk Indices"

No. 93-108 Jon D. Haveman

"The Effect of Trade Induced Displacement on Unemployment and Wages"

No. 93-109 Jon D. Haveman

"Some Welfare Effects of Dynamic Customs Union Formation"

No. 93-110 John A. Carlson, Insook Kim

"Central Banks' Expected Profits From Intervention

If you would like to request copies of specific papers, please contact the Center for International Business Education and Research, Purdue University, Krannert School of Management, West Lafayette, IN 47907.

(Phone: $317 / 494-4463$ or FAX: 317/494-9658) 
No. 94-001 Casper G. De Vries, Phillip A. Stork, Kees G. Koedijk

"Between Realignments and Intervention: The Belgian Franc in the European Monetary System"

No. 94-002 Casper G. de Vries, K. U. Leuven

"Stylized Facts of Nominal Exchange Rate Returns"

No. 94-003 Kent D. Miller

"Operational Flexibility Responses to Environmental Uncertainties"

No. 94-004

Kent D. Miller

"Economic Exposure and Integrated Risk Management"

No. 94-005 Kent D. Miller

"Diversification Responses to Environmental Uncertainties"

No. 94-006 John M. Hannon, Ing-Chung Huang, Bih-Shiaw Jaw

"International Human Resource Strategy and Its Determinants: The Case of Multinationals and Their Subsidiaries in Taiwan"

No. 94-007 John M. Hannon, Ing-Chung Huang, Bih-Shiaw Jaw

"International Human Resource Strategy andControl: The Case of Multinationals and Their

Subsidiaries"

No. 94-008 John M. Hannon, Yoko Sano

"Customer-Driven Human Resource Policies and Practices in Japan"

No. 94-009 John A. Carlson, Insook Kim

"Leaning Against the Wind: Do Central Banks Necessarily Lose?"

No. 94-010 John A. Carlson, David W. Schodt

"Beyond the Lecture: Case Teaching and the Learning of Economic Theory"

No. 94-011 Alok R. Chaturvedi, Hemant K. Jain, Derek L. Nazareth

"Key Information Systems Management Issues in Developing Countries: Differences in the Indian and US Contexts"

No. 94-012 Jon Haveman,

The Influence of Changing Trade Patterns on Displacements of Labor

No. 94-013 Stephen Goldberg

Financial Reporting for Foreign Exchange Derivatives

No. 94-014 Charles Noussair, Charles Plott, Raymond Riezman

Una investigacion experimental sobre la estructura del comercia interncional (Spanish Version)

Translated: An Experimental Investigation About the Structure of International Commerce

No. 94-015 - Marie Thursby, Richard Jensen

Patent Races, Product Standards, and International Competition

No. 94-016 Kent D. Miller, Jeffrey J. Reuer

Firm Strategy and Economic Exposure to Foreign Exchange Rate Movements

No. 94-017 John Hannon, Yoko Sano

The Determinants of Corporate Attractiveness in Japan 
No. 94-018 John Hannon, Ing-Chung Huang, Cheng-Chen Lin

The Mediating Effect of Pre/Post Assignment Acitivities on the Quality of Work Life of Expatriates:

Evidence for Managers in the P.R.C.

No. 94-019 John Hannon, Ing-Chung Huang, Cheng-Chen Lin

The Mediating Effects of Organization Commitment and Job Involvement on the Relationship Between Quality of Work Life and Customer Service Attitudes

No. 94-020 John A. Carlson, Marc Surchat

A Model for Filter-Rule Gains in Foreign Exchange Markets

No. 94-021 Ch.N. Noussair, Ch.R. Plott, R. Riezman

The Principles of Exchange Rate Determination in an International Finance Experiment

No. 94-022 Steven R. Goldberg, Joseph H. Godwin, Myung-Sun Kim, Charles A. Tritschler

On The Determinants of Corporate Hedging With Financial Derivatives

If you would like to request copies of specific papers, please contact the Center for International Business Education and Research, Purdue University, Krannert School of Management, West Lafayette, IN 47907.

(Phone: 317/494-4463 or FAX: 317/494-9658) 